SECTION 30. Philosophy.

Kamalova Olga Nikolayevna candidate of philosophical Sciences, Rostov state medical University, Russia

\title{
AESTHETIC WORLDVIEW AND EVOLUTION PROBLEMS OF INTELLECTUAL INTUITION IN THE GERMAN CLASSICAL PHILOSOPHY
}

The purpose of this scientific article is to study the problem of intuition in German philosophy.

Keywords: philosophy, worldview, intuition.

\section{ЭСТЕТИЧЕСКОЕ МИРОВОЗЗРЕНИЕ И ЭВОЛЮЦИЯ ПРОБЛЕМЫ ИНТЕЛЛЕКТУАЛЬНОЙ ИНТУИЦИИ В НЕМЕЦКОЙ КЛАССИЧЕСКОЙ ФИЛОСОФИИ}

Цель данной научной статьи - исследование проблемы интуиции в немеикой философии.

Ключевые слова: философия, мировоззрение, интуиция.

В Немецкой классической философии, и в частности, в работах Шеллинга проблема интеллектуальной интуиции занимает важное место. «Интеллектуальное созерцание - пишет он в «Философских письмах о догматизме и критицизме», - возникает тогда, когда мы перестаем быть объектом для самих себя, когда созерцающее Я, замкнувшись в себе, становится тождественным созерцаемому Я. В этот момент созерцания для нас исчезает время и длительность: не мы находимся во времени, а время или скорее не время, а чистая абсолютная вечность - находится в нас, не мы растворились в созерцании объективного мира, а мир растворился в нашем созерцании»[1, с. 69].

В отличие от Фихте, Шеллинг обосновывает свою точку зрения с позиции объективного идеализма: «Фихте, - пишет он, - обратился к интеллектуальному созерцанию, чтобы доказать существование «Я»... У меня же... говорится не о Я как непосредственно достоверном - в качестве которого оно выступает в интеллектуальном созерцании, а о том, что получено в интеллектуальном созерцании..., об извлеченном из интеллектуального созерцания, то есть о всеобщем, лишенном определения субъект - объекте. ...Речь уже идет совсем не о существовании, а только о чистом содержании, о сущности того, что содержалось в интеллектуальном созерцании» [2, с. 515]. 
Тенденция противопоставления интуитивного и дискурсивного характерна для позднего периода деятельности философа. При этом надо отметить, что иррациональный мотив, четко выраженный лишь в поздних произведениях Шеллинга, проявляется и в ранний период его творчества в эстетизме, признаками которого является преувеличение значимости искусства по сравнению с другими сферами деятельности, культ художественного гения, значение воображения и чувств в процессе познания и т.д. Шеллинг высказывается об интеллектуальной интуиции, как о «поэтическом даре» или «творческой способности», которая присуща лишь избранным лицам.

Учение Шеллинга об интуиции и искусстве и философии вызвали положительную реакцию среди представителей немецкого художественного и философского романтизма. Что касается Гегеля, то с позиции идеалистической диалектики он подверг критике ряд мировоззренческих установок Шеллинга и немецких романтиков. Он выступил, например, не против поэзии вообще, а против «поэзии» в философии, романтического культа гениальности и шеллингианского элитаризма. Гегель настаивает на том, что философия может плодотворно развиваться лишь в рационально-понятийной форме. По Гегелю, не искусство, а именно наука (т.е. спекулятивная философия) являет в системе своих понятий объективный и всеобщий образ высшей целостности, целостности Абсолюта.

Гегелевская критика распространилась также на понятие интуиции. С точки зрения философа, то что в большинстве случаев выдается за истину оказывается лишь субъективным «уверением», чувствованием и, следовательно, лишь единичным и случайным фактом. Знание, говорит Гегель, всегда мышление, а мышление есть процесс, движение. Познание завершается в «чистом мышлении», и только достигнув этого пункта становится возможным и истинное интеллектуальное созерцание. «Завершенное познание является достоянием исключительно чистого мышления, понимающего разума; и только тот, кто возвысился до этого мышления, обладает совершенно определенным истинным созерцанием; для него созерцание составляет только наиболее подходящую форму, в которой снова концентрируется его уже совершенно развитое познание» [3, с. 252]. Это «одухотворенное, истинное созерцание», которое «охватывает субстанцию предмета во всей его полноте» [там же, с. 251], по признанию самого философа, в некотором смысле совпадает с интеллектуальной интуицией Шеллинга. Не отрицая возможности такого созерцания, Гегель отрицает непосредственный характер, являемого в нем знания.

В философии Гегеля интеллектуальное созерцание играет подчиненную роль по отношению к понятийному (чистому) мышлению. С этих позиций он критикует философию «веры и чувства» Якоби, 
подвергает критике романтический эстетизм и взгляды Шеллинга. Но если по отношению к Якоби, Фр. Шлегелю, Фр. Шлейермахеру гегелевская критика вполне обоснована и понятна, то гораздо менее она справедлива, на наш взгляд, по отношению к ранним философским воззрениям Шеллинга. Гегель не заметил, или не хотел замечать, что непосредственность знания у Шеллинга не так уж безнадежна и совсем не абсолютна. Другое дело поздняя философия Шеллинга. Здесь расхождения с Гегелем носят принципиальный характер. Разрыв Гегеля и Шеллинга, антигегельянство последнего по всей видимости явилось поворотным пунктом в истории немецкого философского идеализма. «Философия Откровения» - такое название получило позднее учение Шеллинга. Центром его критики стал философский рационализм, получивший у Гегеля радикальную форму панлогизма. Разрыв действительного и разумного, отрицание методологической доступности бытия рациональному познанию - таковы противопоставленные Гегелю основные положения «Философии откровения». Логика здесь отвергается Шеллингом потому что она претендует на адекватное отражение действительности. По мнению Шеллинга, мышлению доступно лишь возможное (бесконечная потенция бытия), но не действительное бытие, претендуя на познание которого оно обнаруживает свое бессилие.

Исключая действительное, сущее, реальное из сферы логического познания, Шеллинг противопоставляет ему иной, распространенный не на возможность, а на действительность род познания. Действительность, согласно Шеллингу, становится доступной философии, когда она руководствуется не тем что дано в мышлении или чувственном восприятии, а тем что дано в сверхчувственном созерцании, «мистическом опыте». Отстаиваемая Шеллингом позиция получила название «позитивной философии» в отличие от негативной, под которой философ подразумевает теперь свою прежнюю философию тождества. Эволюционировала и идея интуиции. В целом можно сделать вывод, что в раннем эстетизме Шеллинга и тем более в его поздней философии закладываются основы неклассического понимания интуиции в новейшей философии.

\section{Литература}

1. Шеллинг Ф.В.Й. Сочинения в 2-х т. М., 1987. Т. 1.

2. Шеллинг Ф.В.Й. Сочинения в 2-х т. М., 1989. Т. 2.

3. Гегель Г.В.Ф. Энциклопедия философских наук. Философия духа // Сочинения. М., 1956. Т. 3.

4. Шеллинг Ф.В.Й. Философия искусства. М., 1999.

5. Камалова О.Н. Проблема интуитивного познания в иррациональной философии // Гуманитарные и социально-экономические науки. 2010. № 4. 